Journal of Applied Finance \& Banking, Vol. 11, No. 1, 2021, 81-97

ISSN: $1792-6580$ (print version), 1792-6599 (online)

https://doi.org/10.47260/jafb/1116

Scientific Press International Limited

\title{
Non-Performing Loan Recovery: The Case of Mongolia
}

\section{Davaajargal Luvsannyam', Enkhtur Minjuur², Dulguun Lkhagvadorj ${ }^{3}$ and Enkhsuren Bekhbat ${ }^{4}$}

\begin{abstract}
In this study, the activities related to the recovery of non-performing loans were considered in case of "Savings Bank" LLC. According to the survey, it takes an average of 4.2 years to recover non-performing loans, and recovery rate is on average 83 percent. The recovery rate of loans has been declining over time despite the fact that it was high in the first years of the receiver's appointment. Furthermore, the amount of non-performing loans recovered out-of-court was relatively small compared to the amount of that recovered through the courts. Although in-court activities to recover the non-performing loans takes 1.3 years more than out-of-court, the recovery rate is $7 \%$ higher in terms of judicial proceedings.
\end{abstract}

JEL classification numbers: G21, G29, G33.

Keywords: Non-performing loans, Recovery rate, Banking sector.

${ }^{1}$ Director of Research Division, the Bank of Mongolia.

2 Receiver of Savings Bank LLC.

3 Senior economist, Research Division, the Bank of Mongolia.

${ }^{4}$ Senior Legal Counsel, office of Receiver of Savings Bank.

Article Info: Received: October 21, 2020. Revised: November 9, 2020.

Published online: November 16, 2020. 


\section{Introduction}

Deteriorating bank lending quality is one of the main factors increasing the vulnerability of the financial sector. For example, examples of international banking and financial crises clearly show that the rapid growth of non-performing loans (NPLs) can adversely affect banks' operations and lead to financial instability (Demirgüç - Kunt and Detragiache, 1998; González - Hermosillo, 1999; Hoggarth et al., 2004; Laeven, 2016). Therefore, strengthening the credit risk management of the banking sector, improving the methods and practices for effective recovery of non-performing loans, and taking other necessary measures are important to reduce the cost of credit risk (Dimitrios, 2016).

Today, 14 commercial banks, 3 receivers (Zoos Bank, Savings Bank, Capital Bank) and 538 non-bank financial institutions (NBFIs) are engaged in non-performing assets (Non-Performing Loans or NPLs), in the financial sector of Mongolia. However, in Mongolia, there are no previous reports, studies, analytical methods, and experience on non-performing or bad loans.

This shows that since Mongolia's transition to a two-tier banking system, legislators, policymakers, investors, and financial institutions have been without clear research and public information on the methods, experience, timing, and efficiency of nonperforming loans recovery. For example, Mongolian legislators, policymakers, and foreign and domestic investors often have asked the two questions, "What is the average period for recovering non-performing loans?"; "What is the average recovery rate for non-performing loans?".

In addition, this type of international research has yielded different results depending on the country's banking, financial, and economic characteristics in terms of non-performing loan recovery methods, practices, policies, controls, and regulations (Woo, 2000, Shih, 2004, Xu, 2005, Matoušek and Sergi, 2005).

Therefore, this is the first study conducted in Mongolia aims to clarify the above two questions and find answers to other questions. In addition to laying the groundwork for further research and analysis, their methods and practices needed to identify, select and develop cost-effective methods and solutions for lowering interest rates and non-performing assets in the country, this work will also be helpful in reduction of interest rates and decrease in non-performing assets. Moreover, it is important to support the search in optimal solutions.

The survey included information on a total of 660 (non-performing) assets (loans) settled by the receiver of Savings Bank LLC from July 22, 2013 to December 31, 2019 used as a case study.

\subsection{Assets in the balance of the receiver of the Bank in Savings Bank LLC}

On July 22, 2013, the Bank of Mongolia appointed the receiver to the Savings Bank LLC and decided to liquidate Savings Bank LLC as a legal entity.

Savings Bank was an influential bank that accounted for 15.9 percent of the total depositors in the banking system at the time of the appointment. The difference of MNT 119.9 billion will be paid to the Deposit Insurance Corporation. Accordingly, 
'bad assets' or a total of MNT 191.5 billion in assets and MNT 119.9 billion in payables to others remained in the balance of the Savings Bank.

In addition to its NPLs, the Savings Bank's non-performing assets include nonperforming assets transferred from Mongol Post Bank (MPB) to the Savings Bank in March 2010.

\subsection{Survey data collection}

In the study, the NPLs of Mongol Post Bank transferred to the Savings Bank were identified as "MPB NPLs" in terms of assets type, and the assets of the Savings Bank were differentiated and compared. Assets marked "SB NPLs" are NPLs which belongs to the Savings Bank.

Among the total assets of the Savings Bank, the loan files of the Mongol Post Bank were incomplete, the loan interests were collected manually, the registrations were offline, the statute of limitations for claiming the loan agreement expired before the receiver was appointed, and the bank's registration software changed after the loans were issued. The most common of these problems were disruption of the lending transaction due to the change, inaccessibility, and discrepancies in the registration due to incorrect entry of the borrower's personal information in the computer program. Therefore, it should be noted that it was also the most challenging issue to collect research data.

\subsection{About the borrower's loan recovery process}

In accordance with the Banking Law, the receiver sells the above-mentioned nonperforming assets and transfers the assets transferred to the ownership of the Savings Bank based on the loan liabilities, including the Deposit Insurance Corporation, the Bank of Mongolia, the State Bank and the Tax Authority. Regularly reports to the Bank of Mongolia on the progress, results, and risks of its operations.

Since August 2017, the receiver has shifted its NPLs settlement to a "teamwork" system and operates within the framework of the following principles. These include:

- Repay NPLs in the shortest possible time and with the highest possible amount,

- In each case of NPLs, to take legal action "to the point",

- Take immediate measures to prevent the value of assets transferred as collateral for NPLs from depreciation, depreciation, protection of value at its current level and not to reduce its value.

NPLs are a complex set of measures that require a lot of work to be done at low cost, depending on the nature of the bank being liquidated. 


\subsection{About the selected indicators for collecting closed loan information:}

In this study, we analyzed a total of 660 closed loans based on the borrower's name, registration number, customer registration, and associated account number for each of the 38 indicators etc.

It should be noted that not all of the issues identified for each of these indicators are covered in this report, as the purpose of identifying and selecting the 38 indicators mentioned above is not only to write this research report but also to further study asset management activities and develop activities in this area.

These indicators included in this report were selected based on the best possible identification of the questions posed in this report, the best possible answers, and the ranking of the most influential factors. For example, determining when a loan was first issued, when it was last repaid when it was classified as a non-performing loan, and when it went to court are important for accurately calculating the statute of limitations for claiming a loan and repaying the loan.

Therefore, in addition to the above 38 indicators and other necessary information related to the research period, it was analyzed by specific sub-sections and collected for each indicator.

\subsection{Determining the date of transfer to non-performing loans:}

Pursuant to Article 2.1.1 of the "Regulation on Asset Classification, Establishment and Disbursement of Asset Risk Fund" approved by the joint order of the Governor of the Bank of Mongolia and the Minister of Finance No. A-155,134 dated June 10, 2019 , classified into categories. These three categories can be summarized in terms of asset maturities in Table 1 .

Table 1: Classification of assets for credit risk management

\begin{tabular}{|c|c|c|c|c|}
\hline & \multicolumn{2}{|c|}{$2019.06 .10(\mathrm{~A}-155 \backslash 134)$} & \multicolumn{2}{|c|}{ 2010.08.11 (475/182) } \\
\hline № & $\begin{array}{c}\text { Asset } \\
\text { classification }\end{array}$ & $\begin{array}{l}\text { By payment } \\
\text { overdue days }\end{array}$ & $\begin{array}{c}\text { Asset } \\
\text { classification }\end{array}$ & $\begin{array}{c}\text { By payment } \\
\text { overdue } \\
\text { days }\end{array}$ \\
\hline 1 & Performing & $\leq 15 ; \leq 30$ & Performing & \\
\hline 2 & Special mention & $\leq 90$ & $\begin{array}{l}\text { Special } \\
\text { mention }\end{array}$ & $\leq 90$ \\
\hline & \multicolumn{2}{|c|}{ Non-Performing of which: } & \multicolumn{2}{|c|}{ Non-Performing of which: } \\
\hline 3.1 & Substandard & $91-180$ & Substandard & $91-180$ \\
\hline 3.2 & Doubtful & $181-360$ & Doubtful & $181-360$ \\
\hline 3.3 & Loss & $\geq 361$ & Loss & $\geq 361$ \\
\hline
\end{tabular}

Although, as mentioned above, "Non-performing" and "Loss" assets are different concepts, they are often referred to as "Bad assets" by the public. In addition, there was no need to classify the Savings Bank's assets as "Performing" or "Doubtful" as they were all classified as "Loss". However, in this study, care was taken to 
determine exactly when each asset was classified as Loss. For some assets, this was difficult to determine, so each asset was considered a non-performing loan from the time it was classified as a non-performing asset. Therefore, for research purposes, the "Non-performing" or "Loss" assets (NPLs) mentioned in this study can be understood together as "Non-performing assets" or "Non-performing loans".

In most cases, the date on which the loan was classified into the non-performing category and the principles and interest balances on that day were used in the calculation.

\subsection{Difficulties in collecting information on closed loans and solutions:}

There were some difficulties in collecting information on the total of 660 closed loans for each of the above indicators and categories. For example, many problems have arisen, such as software discrepancies, incomplete files on loan, misspellings of the borrower's name and registration number, which cannot be found in the program, and have been resolved in an appropriate manner. Here are some of them:

- When classifying total loans, it was difficult to determine the amount and timing of the initial disbursement due to differences in the software used to disburse the loan. For example, loans disbursed before 2008 were often recorded offline or manually, without any software, so the amount of the loan was determined based on the amount of the loan, and the date of the loan agreement was calculated as the date of disbursement. Prior to 2008, the Savings Bank and Mongol Post Bank registered credit card rights in another program, which is now available on only one computer at the State Bank. When the program applied to the State Bank for borrower information, it was not complete, and it took a lot of time. Therefore, for some loans, the Grape bank program determines the amount for which the loan was first registered, the date the loan was first issued, and the loan amount.

- Although the original date of issue is calculated from the date of the loan transaction, as mentioned above, it was not possible to determine the exact amount of the original loan for the loan granted at the time of offline registration and card authorization. The bank determines the amount of loan disbursed and the date of disbursement based on the balance installed in the program.

- To determine the amount of non-performing loans and the transition period to non-performing loans, 80 percent of the total loans have interest accrued, 397 percent have accrued interest offline, no information on how much has been accrued and how much has been repaid. Suddenly the loan interest rate and the increased interest account were opened and the accumulated balance as of the opening date of the account was installed. Therefore, it was not possible to know the loan interest rate and accrued interest balance at the time of transferring these loans to non-performing loans, so the loan interest rate and accrued interest balance were calculated as 0 (zero) MNT. 
- Some borrowers have a long credit history or have taken out multiple loans at the same time, making it difficult to determine the amount of non-performing loans, total loans disbursed, and loans repaid. An example of this is a pension loan, in which a borrower borrows more than once, and the loan is accrued over a long period of time, depending on the size of the pension and the interest rate, such as a monthly loan. In this case, the date of the first loan is determined by the date of the first loan, and the loan amount is calculated as the total loan amount.

- For loans repaid in USD, it was not possible to convert the loan into MNT at the current exchange rate due to a lack of information on each recovery date. The loan is translated at the average exchange rate issued by the Bank of Mongolia for the year in which the loan was transferred to the non-performing category.

\section{General information}

Between 2013 and 2019, the receiver of the Savings Bank fully resolved 660 nonperforming assets or loans with a total outstanding loan of MNT 21.0 billion. Of which, $54 \%$ or 11.4 billion MNT was repaid in the performing category, and the remaining $46 \%$ or 9.6 billion MNT in the non-performing category (Table 2).

Table 2: Total loans and non-performing loans (2013-2019)

\begin{tabular}{rrrrrrrr} 
Year & \multicolumn{1}{c}{$\begin{array}{c}\text { Total } \\
\text { loans }\end{array}$} & \multicolumn{1}{c}{ Loans } & NPLs & $\begin{array}{c}\text { \% of NPLs to total } \\
\text { loans }\end{array}$ & $\begin{array}{c}\text { Amount of NPLs } \\
\text { repaid }\end{array}$ & $\begin{array}{c}\text { Repayment rate } \\
\text { of NPLs }\end{array}$ & $\begin{array}{c}\text { Total } \\
\text { repayment }\end{array}$ \\
\hline 2013 & $1,643.0$ & 468.2 & $1,174.8$ & $72 \%$ & 932.7 & $79 \%$ & $1,568.8$ \\
2014 & $8,716.5$ & $6,487.4$ & $2,229.1$ & $26 \%$ & $1,637.8$ & $73 \%$ & $8,777.4$ \\
2015 & $2,865.6$ & $1,206.6$ & $1,659.0$ & $58 \%$ & $1,605.2$ & $97 \%$ & $3,896.7$ \\
2016 & 504.1 & 264.8 & 239.3 & $47 \%$ & 187.4 & $78 \%$ & 596.9 \\
2017 & 506.3 & 187.6 & 318.7 & $63 \%$ & 214.1 & $67 \%$ & 536.8 \\
2018 & $5,669.7$ & $2,518.6$ & $3,151.0$ & $56 \%$ & $3,081.8$ & $98 \%$ & $6,255.7$ \\
2019 & $1,132.9$ & 291.6 & 841.3 & $74 \%$ & 583.0 & $69 \%$ & $1,016.2$ \\
\hline Total & $\mathbf{2 1 , 0 3 8 . 2}$ & $\mathbf{1 1 , 4 2 4 . 9}$ & $\mathbf{9 , 6 1 3 . 2}$ & $\mathbf{4 6 \%}$ & $\mathbf{8 , 2 4 2 . 1}$ & $\mathbf{8 6 \%}$ & $\mathbf{2 2 , 6 4 8 . 4}$
\end{tabular}

By end of 2019, MNT 8.2 billion of the non-performing loans out of total MNT 9.6 billion have been recovered, and the recovery rate of non-performing loans each year is ranging from $67 \%$ to $98 \%$. During this period, the amount of loans increased by 1.08 times and 22.6 billion MNT was repaid. Of the 660 non-performing assets surveyed, the lowest value was MNT 39,000, whereas the highest was MNT 4 billion. 


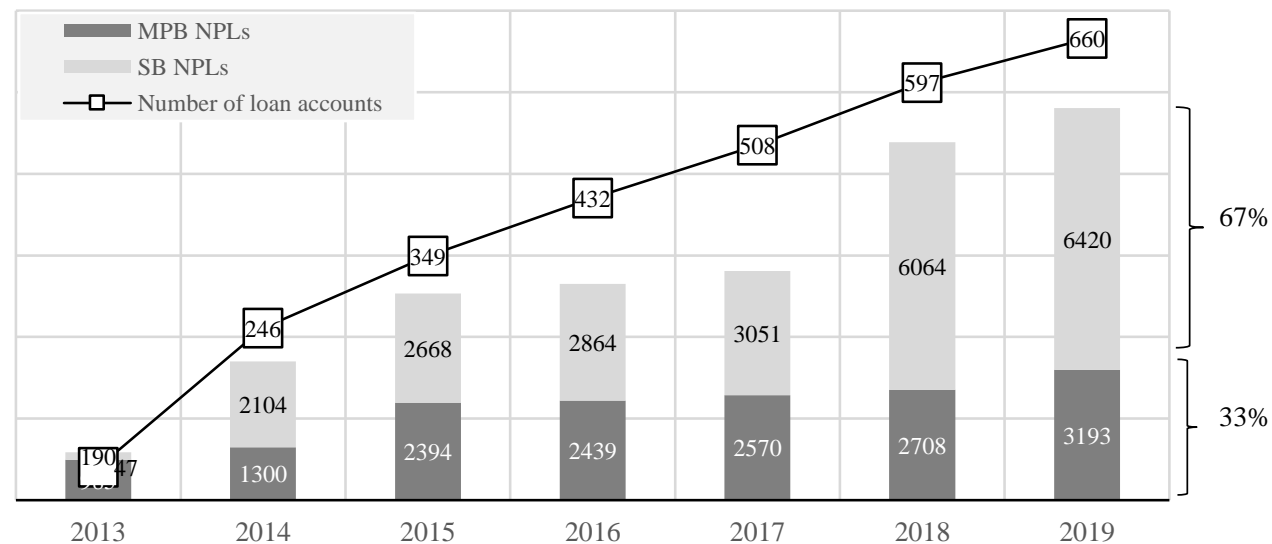

Figure 1: Composition of NPLs, by assets forms (in stock)

As for asset type, 67\% of total non-performing loans or MNT 6,420 million are SB NPLs, while 33\% or MNT 3,193 million are long-term MPB NPLs. In terms of the numbers, $70 \%$ or 462 are SB NPLs and $30 \%$ or 198 are MPB NPLs (Figure 1, 2).

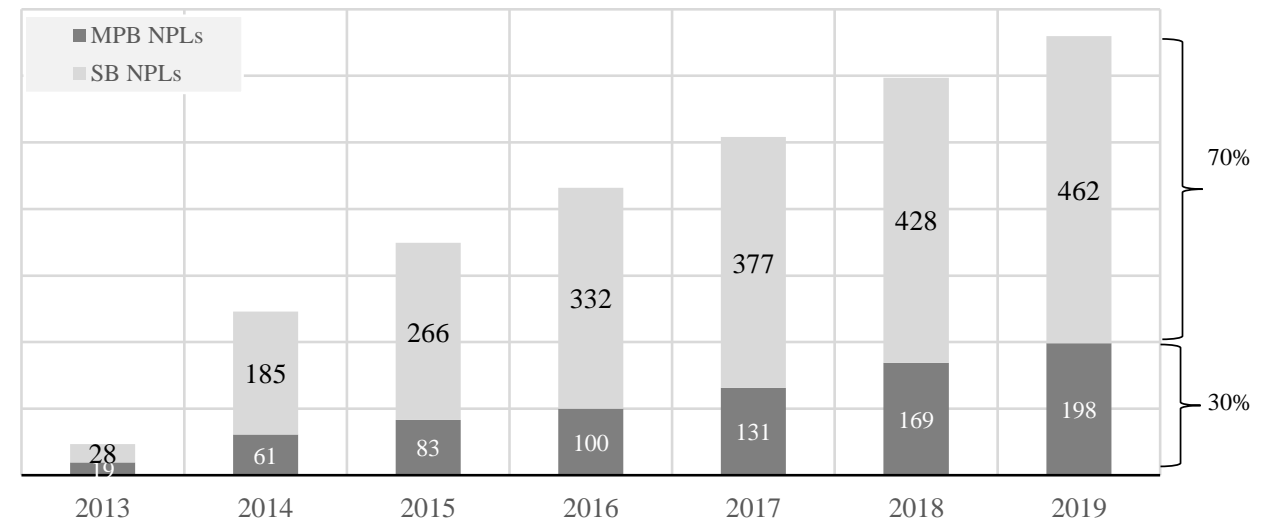

Figure 2: Total number of MPB NPLs and SB NPLs (in stock)

Between 2013 and 2019, the average number of SB NPLs recovered was 66, while the 28 MPB NPLs were recovered on average per year. The Figure 3 shows that the number of SB NPLs recovered has been declining year by year, whereas the number of MPB NPLs payments has been higher than the average in recent years. One of the reasons for the increase in the number of MPB NPLs payments was the transfer of NPLs recovery activities to a 'teamwork' system. This is because prior to August 2017, the Bank's receivership process traditionally mandated the settlement of many more NPLs per individual or a NPL collector, rather than 'teamwork'. Because it involves a large number of NPLs per person, there was a tendency to 'sample' from 
the individual due to criteria such as the fastest, most reliable, least efficient, and highest amount. As a result, the most active and least repayable NPLs were delayed.
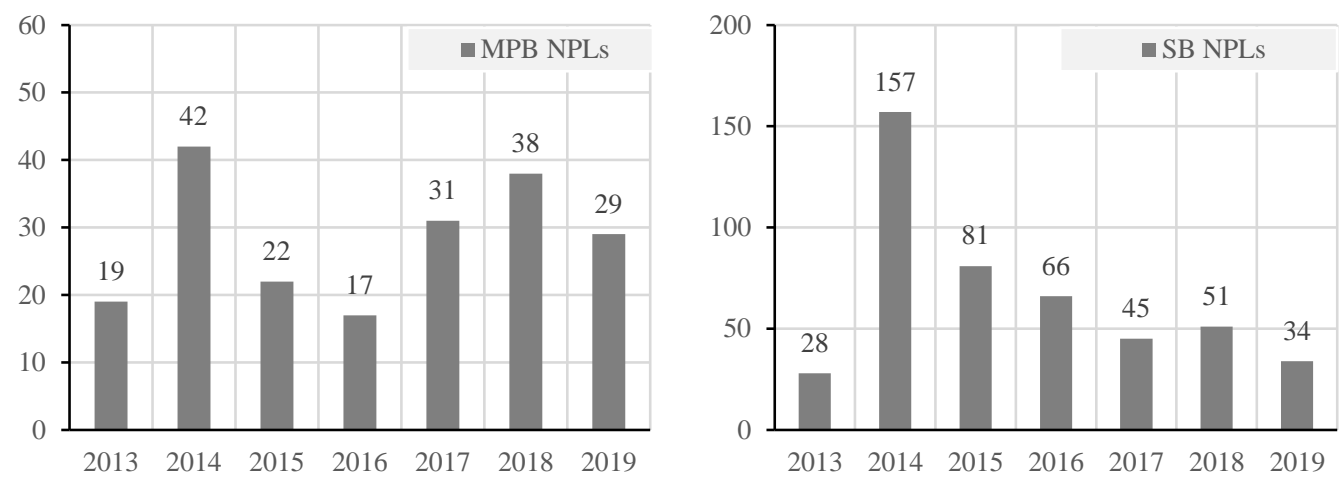

Figure 2: Change in number of MPB NPLs and SB NPLs repaid

This is due to the fact that the number of SB NPLs that can be repaid is decreasing year by year, on the other hand, it is more difficult to repay, the borrower is reluctant to repay, and there is little opportunity to go to court (no personal need, the expired statute of limitations, etc.). In addition, the structure of non-performing assets is classified as (i) the currency in which they are issued, (ii) the individual or legal entity, (iii) the geographical location, and (iv) the judicial and non-judicial settlement, as shown in Figure 4.
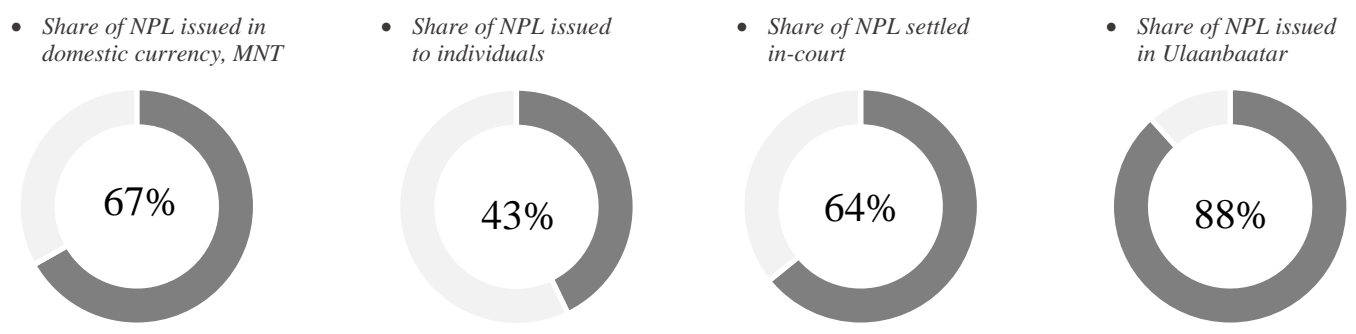

Figure 3: Composition of NPLs by various categories

According to the statistics showed in Figure 4, 67\% of total non-performing loans or MNT 6,421 million are issued in domestic currency, MNT, while 33\% or MNT 3,192 million are issued in foreign currency.

Moreover, MNT 4,118 million or 43\% of total non-performing loans are issued to individuals and MNT 5,495 million are issued to legal entities. In terms of the court activity, $64 \%$ of total non-performing loans are settled in court, while $36 \%$ of it were settled out of court. Also, loans issued in the capital city, Ulaanbaatar, accounted for $88 \%$ of total non-performing loans. 


\subsection{Non-performing loan's recovery time}

This section discusses the time required to recover a non-performing loan. If we classify the total number of non-performing assets by term, half of them, or about 330 loans, were settled within 4 years (Figure 5). However, considering the number of bills paid, it took a relatively long time, more than 4 years.

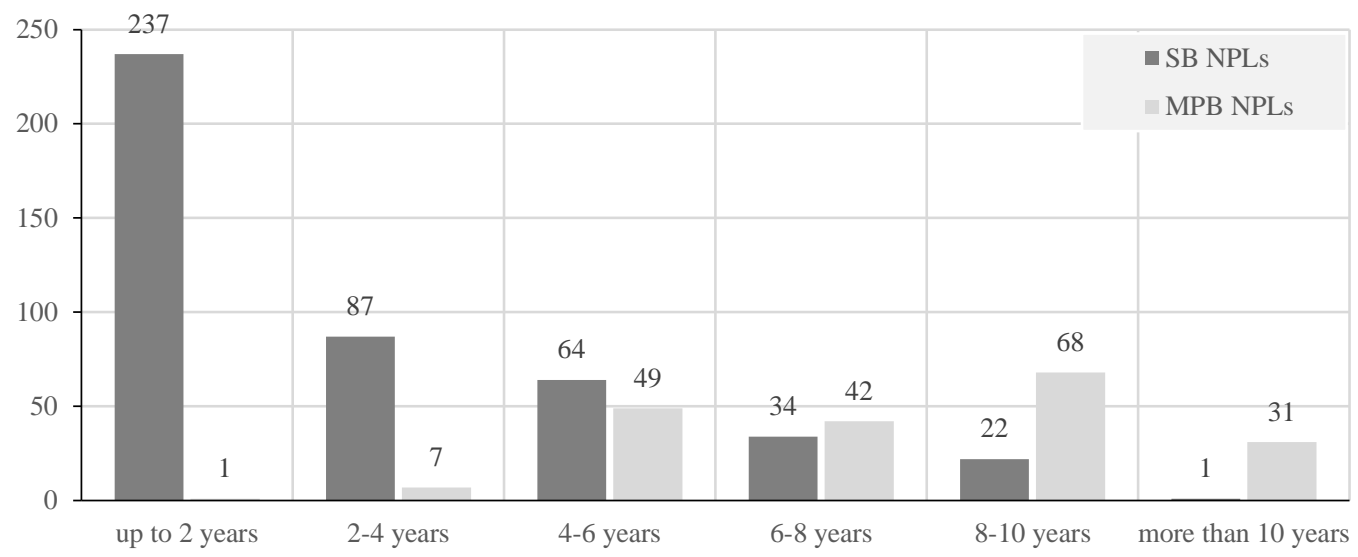

Figure 4: Total number of MPB NPLs and SB NPLs (in stock)

The time required to settle all non-performing assets is 4.2 years on average. In terms of assets forms, the period of the MPB NPLs is 7.7 years, and the SB NPLs is 2.7 years (Figure 6).

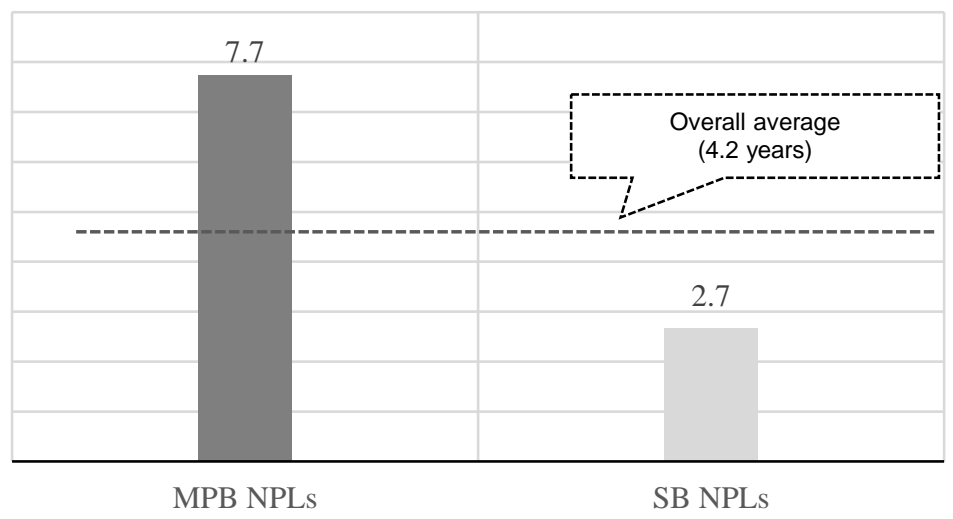

Figure 5: Average period required to recover NPL (in years)

Of these, the minimum time spent on court-settled assets is 134 days and the maximum is 6,058 days or 16.6 years (including the time taken by the three-tier 
courts and the Executive Agency of Court Decision (EACD). The minimum time spent on non-judicial assets is 4 days and the longest period is 4633 days or 12.7 years. In addition, the longest recovery period since the date of the loan was 24.5 years, and the loan was provided by Mongol Post Bank in 1993.

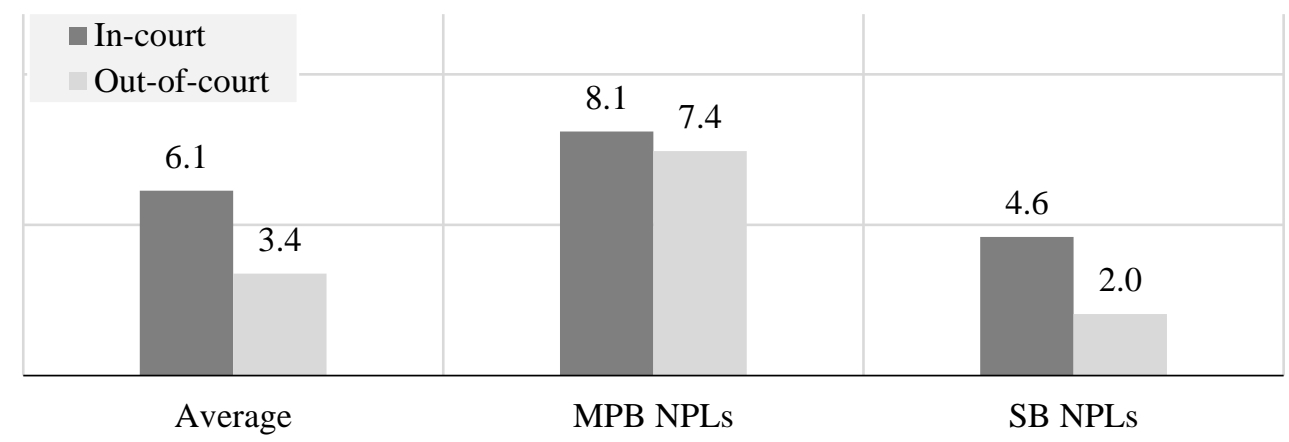

Figure 6: Average period to recover NPL settled in court (in years)

Also, the time required to recover a non-performing loan are varies depending on solving the methods. For example, it takes an average of 6.2 years to resolve in a court case, while a non-judicial process takes twice as short, 3.4 years (Figure 7). This is the same trend in terms of asset forms, as both MPB NPLs and SB NPLs take longer time to settle through the court.

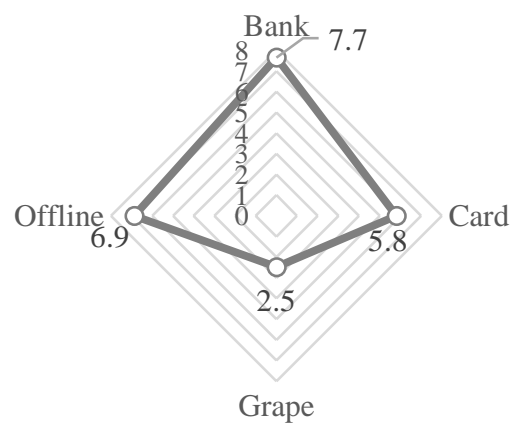

Figure 8: Average period required for recovery of NPL by loan registration software

Non-performing loans have different recovery periods due to differences in banking registration software. For example, due to the transition to Grape software, the loan recovery period has been reduced to 2.5 years (Figure 8). 
Table 3: Average period of execution of court decision for NPL recovery

\begin{tabular}{cccc} 
& $\begin{array}{c}\text { Amount } \\
\text { /MNT million/ }\end{array}$ & $\mathbf{\%}$ of & Nnumber \\
\hline Loans settled in court & $\mathbf{6 1 6 7 . 8}$ & $\mathbf{1 0 0 \%}$ & $\mathbf{1 9 8}$ \\
of which: Court decisions executed by EACD & 3449.0 & $56 \%$ & 108 \\
Otherwise & 2718.8 & $44 \%$ & 90 \\
\hline
\end{tabular}

Of the 198 loans totaling MNT 6,167.8 million, 56\% or 3,449 were repaid through the $\mathrm{EACD}^{5}$, while the remaining $44 \%$ or MNT 2718.8 million were repaid without access to the EACD (Table 3).

\subsection{Volume of NPLs and recovery rate}

This section discusses the amount of non-performing loans recovered. Figure 9 and 10 compares the total loan outstanding with the amount repaid or repaid in terms of the time taken to repay the loan. For example, as for loans that have been required the up to 4 years to be recovered, the loan amount has been recovered by an average of about 22 percent of the original loan amount (Figure 9).

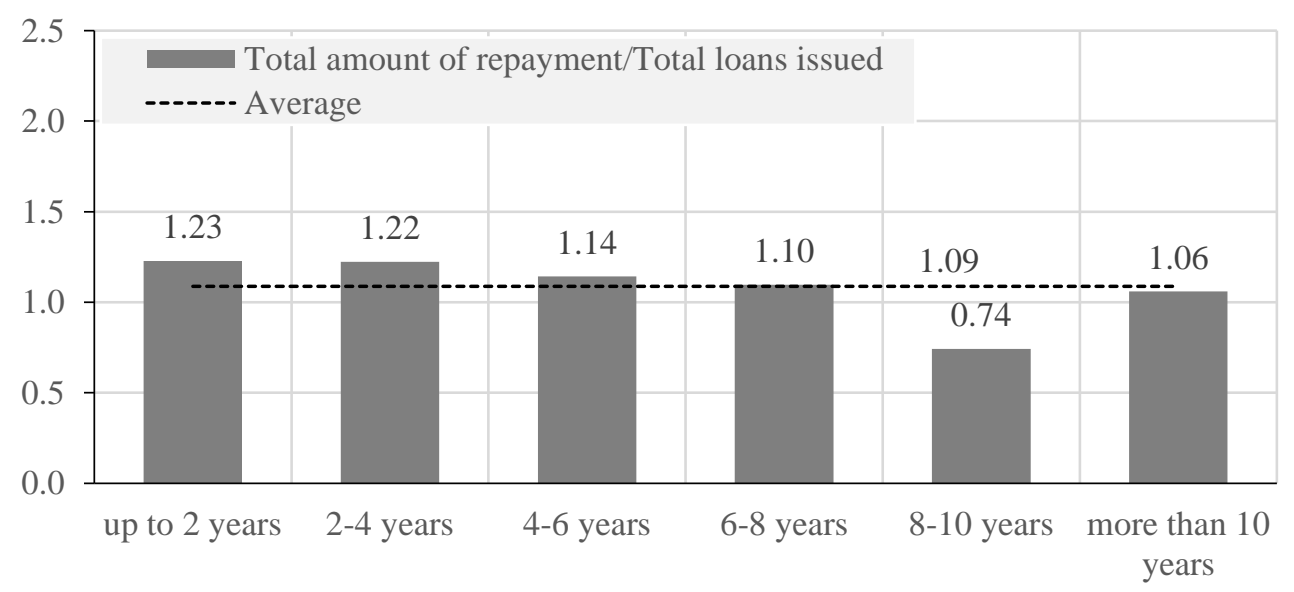

Figure 7: Ratio of repaid loans to total loans issued

However, when the loan maturity was extended and it took about 8-10 years, about 74 percent of the loan balance was repaid. Looking at the total amount between 2013 and 2019, loans of MNT 20.0 billion were repaid to MNT 22.6 billion, or $108 \%$ of total loans.

\footnotetext{
${ }^{5}$ Executive Agency of Court Decision
} 


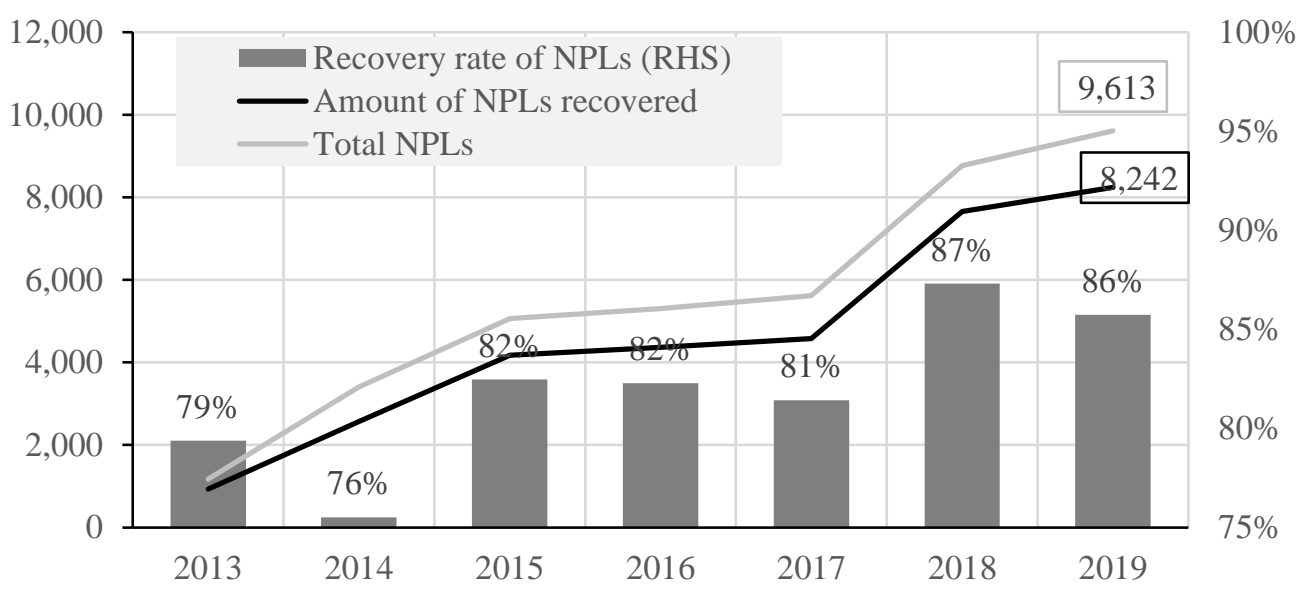

Figure 8: Ratio of recovered NPLs to total NPLs (accumulated)

In terms of non-performing loans, MNT 5,628 million out of MNT 6,168 million were repaid, or $91 \%$ of the total non-performing loans. Non-judicial loans, on the other hand, have a relatively low recovery rate of $76 \%$ (Figure 11 ).

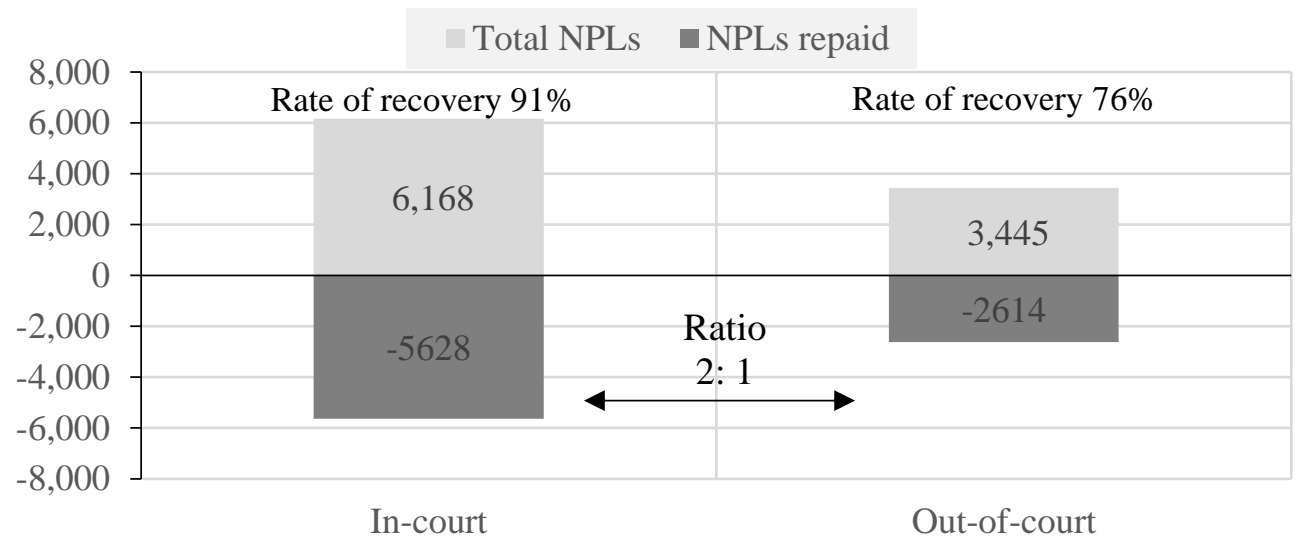

Figure 9: NPLs settled in-court and out-of-court (million MNT)

Moreover, 198 loan claims equivalent to MNT 9,663 million were appealed to the court, and of which MNT 8,748 million or 175 loan claims satisfied the court decisions. Therefore, the percentage of court-satisfied claims is around $88-91 \%$ (Table 4).

Table 4: Claims and enforcement of court decisions

\begin{tabular}{lcc} 
& Number of NPLs & Amount of NPLs /MNT million / \\
\hline Loan claims & 198 & 9663 \\
Enforcement of court decision & 175 & 8748 \\
\hline Claim settlement ratio & $\mathbf{8 8 \%}$ & $\mathbf{9 1 \%}$
\end{tabular}



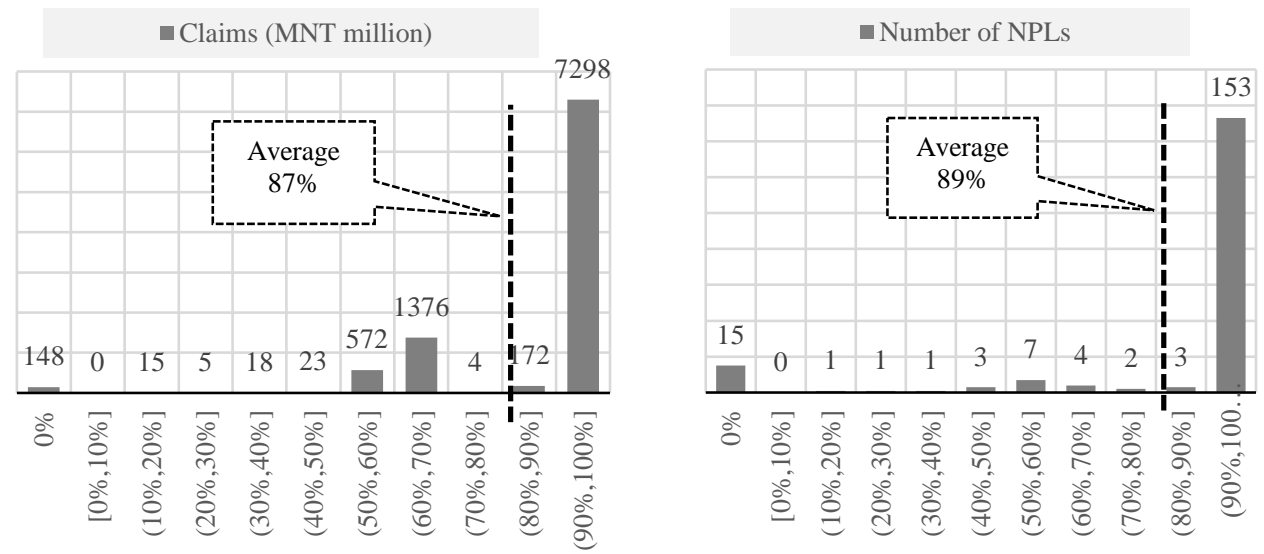

Figure 12: Interval of claims settlement ratio (in terms of the amount of NPLs)

If we look at the Figure 12 that shows the percentage of loan claims satisfied by the court at intervals, 153 loan claims accounting to MNT 7,298 million were resolved with the highest percentage of 90-100\%. Figure 13 shows the comparisons of the amount of recovered non-performing loans by specific categories.
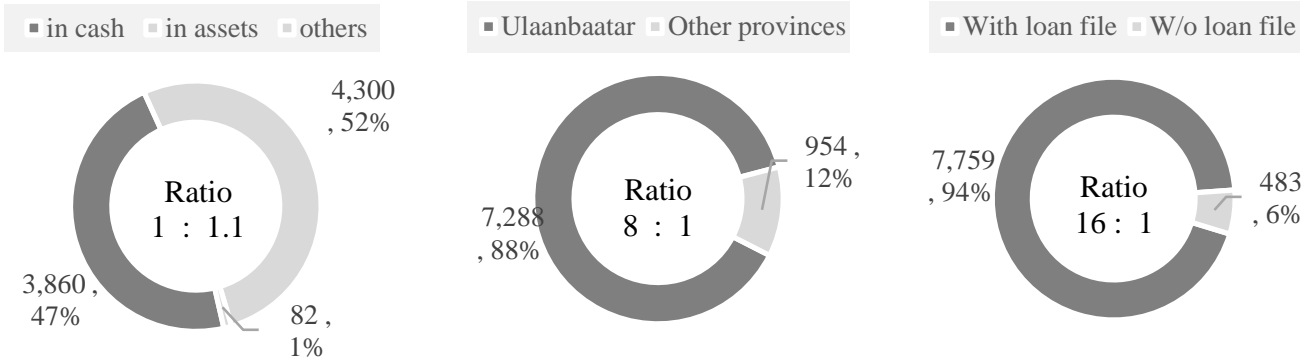

\section{Figure 10: Interval of claims settlement ratio (in terms of the amount of NPLs)}

Non-performing loan recovered in Ulaanbaatar accounts MNT 7,283 million and it is 8 times higher than in rural areas. The amount of recovered non-performing loans in cash equals to MNT 3,860 million and 1.1 times lower than the amount in assets and others. The amount of non-performing loans with files is 16 times higher than that without loan files.

\section{The data and methodology}

As stated in section 1, data information is collected by the receiver of Savings Bank LLC. By omitting the incomplete data, econometric analysis based on the total of 624 non-performing assets from July 22, 2013 to December 31, 2019.

In this section, we estimate empirical linear regression models in order to evaluate 
what specific factors affecting recovery period and rate as in research questions. The regression models are specified in equation 1.

$$
Y_{j i}=\alpha_{0}+\alpha_{1} X_{i}+e_{i}
$$

The dependent variable $y_{1 i}$ is the years required for NPL resolution (Model 1 and Model 2), whereas $y_{2 i}$ is NPLs recovery rate that (Model 3 and Model 4). The dependent variables are identical in all models and determined as follows:

$$
\begin{aligned}
& x_{1}=\left\{\begin{array}{c}
1, \text { if NPLs settled in }- \text { court } \\
\text { otherwise } 0 ;
\end{array}\right. \\
& x_{2}=\left\{\begin{array}{c}
1, \text { asset type is MPB NPLs } \\
\text { otherwise } 0 ;
\end{array}\right. \\
& x_{3}=\left\{\begin{array}{c}
1, \text { if registration system is Grape system } \\
\text { otherwise } 0 ;
\end{array}\right. \\
& x_{4}=\left\{\begin{array}{c}
1, \text { if borrower is individual } \\
\text { otherwise } 0 ;
\end{array}\right. \\
& x_{5}=\left\{\begin{array}{c}
1, \text { loans issued in UB } \\
\text { otherwise } 0 ;
\end{array}\right. \\
& x_{6}=\left\{\begin{array}{c}
1, \text { NPLs is in domestic currency } \\
\text { otherwise } 0 ;
\end{array}\right. \\
& x_{7}=\left\{\begin{array}{c}
1, \text { NPLs are resolved thorough EACD } \\
\text { otherwise } 0 ;
\end{array}\right. \\
& x_{8}=\left\{\begin{array}{c}
1, \text { if NPLs paid in cash } \\
\text { otherwise } 0 ;
\end{array}\right. \\
& x_{9}=\left\{\begin{array}{c}
1, \text { if borrower has loan file } \\
\text { otherwise } 0 ;
\end{array}\right.
\end{aligned}
$$

here, $e_{i}$ is residual term that is normal i.i.d. The model parameters are estimated with OLS techniques and estimation results are shown in Table 5. 
Table 5: OLS estimation result

\begin{tabular}{|c|c|c|c|c|}
\hline & (Model 1) & (Model 2) & (Model 3) & (Model 4) \\
\hline Variables & $y_{1}$ & $y_{1}$ & $y_{2}$ & $y_{2}$ \\
\hline \multirow[t]{2}{*}{ In-court } & $2.608 *$ & $1.289 * * *$ & $.0781 *$ & $0.0725 * *$ \\
\hline & [.384] & {$[0.270]$} & [.029] & [0.0332] \\
\hline \multirow[t]{2}{*}{ In-court*EACD } & .221 & 0.185 & & 0.0294 \\
\hline & [.441] & {$[0.302]$} & & {$[0.0326]$} \\
\hline \multirow[t]{2}{*}{ MPB NPLs } & & $2.636 * * *$ & & 0.0306 \\
\hline & & [0.327] & & {$[0.0334]$} \\
\hline \multirow{2}{*}{ Grape system } & & $-2.664 * * *$ & & $0.0595^{*}$ \\
\hline & & [0.351] & & {$[0.0376]$} \\
\hline \multirow[t]{2}{*}{ Individual } & & -0.0885 & & -0.0603 \\
\hline & & [0.744] & & {$[0.146]$} \\
\hline \multirow[t]{2}{*}{ Ulaanbaatar } & & -0.0364 & & $0.0422 * *$ \\
\hline & & [0.189] & & {$[0.0192]$} \\
\hline \multirow[t]{2}{*}{ In domestic currency } & & -0.173 & & 0.298 \\
\hline & & [0.800] & & {$[0.211]$} \\
\hline \multirow[t]{2}{*}{ In cash } & & $-2.426 * * *$ & & $0.585 * * *$ \\
\hline & & {$[0.263]$} & & {$[0.0477]$} \\
\hline \multirow[t]{2}{*}{ With loan file } & & $0.661 * * *$ & & $0.0844 * *$ \\
\hline & & [0.181] & & {$[0.0365]$} \\
\hline \multirow[t]{2}{*}{ Constant } & $3.384 *$ & $6.530 * * *$ & $.80844^{*}$ & -0.0662 \\
\hline & {$[.156]$} & [1.067] & {$[.0180]$} & {$[0.251]$} \\
\hline Observations & 624 & 624 & 624 & 624 \\
\hline R-squared & 0.135 & 0.664 & 0.01 & 0.374 \\
\hline
\end{tabular}

Robust standard errors in brackets

$* * * \mathrm{p}<0.01, * * \mathrm{p}<0.05, * \mathrm{p}<0.1$

According to the OLS estimation result in Table 5, in-court has significantly positive impact on both dependent variables, period of recovery and recovery rate, at $5 \%$ significant level. When NPLs are settled in-court the recovery period is 1.3 years greater than out of-court. The step-by-step process of enforcing a court decision will be carried out in accordance with the law, even if the 'unnecessary' process is repeated, some activities are omitted, every action required by the law is delayed, and all legal measures are taken. It can be time-consuming and can lead to ineffective deadlocks. However, recovery rate is 7 percent higher than in case of out-court. That means although NPLs are settled in court takes more time, recovery rate is higher and more effective than out-court process or going for negotiating. In addition, if banking registration is Grape software, the loan recovery period has been reduced by 2.6 years and recovery rate is $6 \%$ higher than other software. 
In the case of through the EACD, the loan recovery period has been slightly extended by 0.19 years, but it is not statistically significant. Loans to legal entities are repayable over a relatively long period of time, which means that some loans can be borrowed through another company, run the business, the company has no real assets, no location, is a 'paper company', and has many other loan liabilities.

Moreover, depending on the location of the receiver and the availability of manpower, the lender has more communication and control over the loan if the borrower resides in Ulaanbaatar. As a result, Ulaanbaatar has repaid more loans (recovery rate is $4 \%$ higher than other areas) that have not been repaid for many years and are more difficult to repay than loans issued in the local area. The same is true for loans with files.

The receiver seeks to repay the loan in cash, and if it is not possible to repay the loan in cash and it takes a long time to repay in cash, the borrower assets are taken to liquidate the non-performing loan. Therefore, in terms of time, it took longer than a loan repaid in cash.

\section{Conclusion}

This study is the first of its kind to attempt to determine the average maturity and average recovery rate of non-performing loans. The average maturity to recover the non-performing loans is 4.2 years and recovery rate are 83 percent. Although the recovery rate of NPLs was high in the first years of the receiver's appointment, the recovery rate has been declining over time.

However, the amount of non-judicial payments was relatively small compared to the amount of NPLs paid in-court, but in terms of time, it took almost 1.3 years more. The minimum time spent on judicial assets was 134 days ( 0.4 years) and the maximum was 16.6 years, while the time spent on non-judicial assets was a minimum of 1 day and a maximum of 12.7 years. The amount of non-performing loans in Ulaanbaatar are eight times greater and recovery rate is $4 \%$ higher than that in rural areas. The repaid amount of non-performing loans with loan files is 16 times higher than the repaid amount of non-performing loans without loan files. If borrower has loan file NPL recovery period is 0.6 years less and recovery rate is $8 \%$ higher than one without file.

Based on the facts of non-performing loans of Savings Bank LLC, it is important to reduce non-performing loans in the financial sector, solve them in an economically efficient and international standard way, and reduce total costs related to asset management and non-performing loans. Therefore, it is concluded that legislators and policymakers need to determine the best way to recover non-performing loans, improving the legal environment necessary for its implementation, and take economic and financial measures in the near future. 


\section{Referents}

[1] Crises: Evidence from Developed and Developing Countries. IMF Staff papers Vol. 45, No. 1.

[2] Dimitrios, A. (2016). Management and Resolution methods of Nonperforming loans: A Review of the Literature. MPRA Paper No. 77581, Athens University of Economics and Business.

[3] González-Hermosillo, B. (1999). Determinants of ex-ante banking system distress: A macro empirical exploration of some recent episodes. IMF. IMF Working Paper, 33.

[4] Hoggarth, G., Reidhill, J., and Sinclair, P. (2004). On the resolution of banking crises: theory and evidence. Bank of England. BOE Working Paper.

[5] Laeven, L. (2016). Banking Crises: A Review. The Annual Review of Financial Economics, 3(1). doi:10.1146/annurev-financial-102710-144816

[6] Matoušek, R., and Sergi, B. (2005). 'Management of Non-Performing Loans in Eastern Europe. Journal of East-West Business, 11 (1), 141-166.

[7] Shih, V. (2004). 'Dealing with Non-Performing Loans: Political Constraints and Financial Policies in China. The China Quarterly.

[8] Woo, D. (2000). 'Two Approaches to Resolving Nonperforming Assets During Financial Crises. International Monetary. Washington, D.C.:: IMF Working Paper No. 00/33.

[9] Xu, M. (2005). 'Resolution of Non-Performing Loans in China'. School of Business Glucksman Institute for Research in Securities Markets. 